\title{
Histopatologi kejadian obstruksi intestinal pada kucing Persia
}

\author{
Ida Sukma Kuswardhani ${ }^{1}$, Albiruni Haryo ${ }^{2}$, Muhamad Arfan Lesmana ${ }^{3, *}$ \\ ${ }^{1}$ Program Profesi Dokter Hewan, Fakultas Kedokteran Hewan, Universitas Brawijaya, Malang \\ ${ }^{2}$ Departemen Patologi Anatomi, Fakultas Kedokteran Hewan, Universitas Brawijaya Malang \\ ${ }^{3}$ Departemen Klinik, Fakultas Kedokteran Hewan, Universitas Brawijaya, Malang
}

\begin{abstract}
ABSTRAK: Seekor kucing berjenis kelamin betina, dan berumur 2 tahun dibawa ke Rumah Sakit Hewan Pendidikan Universitas Brawijaya dengan kondisi lemas. Keluhan dari pemilik, kucing tidak mau makan, tidak ada muntah, tidak ada diare, dan diberikan vitamin. Kucing Caca menunjukkan suhu tubuh $37,6^{\circ} \mathrm{C}$, mukosa pucat, letarghi, palpasi abdomen tidak terdapat nyeri, tidak terdapat jaundice, dan cuping hidung kering. Pemeriksaan hematologi tampak anemia, trombositopenia, dan limfositopenia. Citra radiografi terlihat adanya benda asing dalam usus halus. Kucing di rawat inap selama 7 hari dan tidak menunjukkan perbaikan perkembangan, mengalami kematian dan dilakukan nekropsi untuk pemeriksaan histopatologi. Pemeriksaan histopatologi organ ileum terlihat adanya rupture pada mukosa hingga lapisan submukosa.
\end{abstract}

Kata kunci:

obstruksi intestinal, korpus alienum, kucing, histopatologi, ileum

\section{- PENDAHULUAN}

Korpus alienum adalah benda asing dari luar yang tidak seharusnya ada di dalam tubuh. Beberapa tempat di mana benda asing sering ditemukan seperti saluran napas, mata, hidung, kulit, perut, hingga anus. Kejadian ini sering pada anjing dan jarang pada kucing (Kyles et al. 1998, Mahajan et al. 2012). Diagnosa penunjang untuk penegakan dioagnosa kasus ini umumnya menggunakan pencitraan radiografi maupun endoskopi dan tindakan enterotomi merupakan langkah yang dapat dilakukan dengan segera untuk menghindari kematian pada pasien (Erwin et al. 2018). Peneguhan diagnosa secara cepat dan penanganan segera dilakukan pada kasus korpus alienum dapat mencegah terjadinya kematian. Kajian histopatologi kasus korpus alienum pada kucing sulit didapatkan. Tulisan ini melaporkan pemeriksaan histopatologi kasus kematian kucing akibat korpus alienum pada ileum.

\section{- KASUS}

Sinyalemen, anamnesa, dan gejala klinis: Seekor Kucing bernama Caca berjenis kelamin betina, dan berumur 2 tahun dibawa ke Rumah Sakit Hewan Pendidikan Universitas Brawijaya dengan kondisi lemas. Keluhan dari pemilik kucing Caca, kucing tidak mau makan, tidak ada muntah, tidak ada diare, dan diberikan vitamin. Kucing Caca telah divaksin terakhir 6 bulan lalu, diberikan obat cacing terakhir 7 bulan lalu, dan pemberian obat kutu terakhir awal bulan setelah grooming.

Pemeriksaan fisik: Kucing Caca menunjukkan suhu tubuh $37,6^{\circ} \mathrm{C}$, mukosa pucat, letarghi, palpasi abdomen tidak terdapat nyeri, tidak terdapat jaundice, dan cuping hidung kering. Hari ke 4 perawatan kucing Caca defekasi pertama kali selama perawatan dengan feses sangat keras (Gambar 1A).
Diagnosa penunjang: Hasil pemeriksaan pada citra radiografi menunjukkan adanya benda asing pada ileum (Gambar 1C dan D). Hasil pemeriksaan hematologi menunjukkan adanya penurunan kadar hemoglobin yang menunjukkan kemungkinan defisiensi zat besi/ Fe, trombositopenia, dan limfositopenia (Tabel 1).
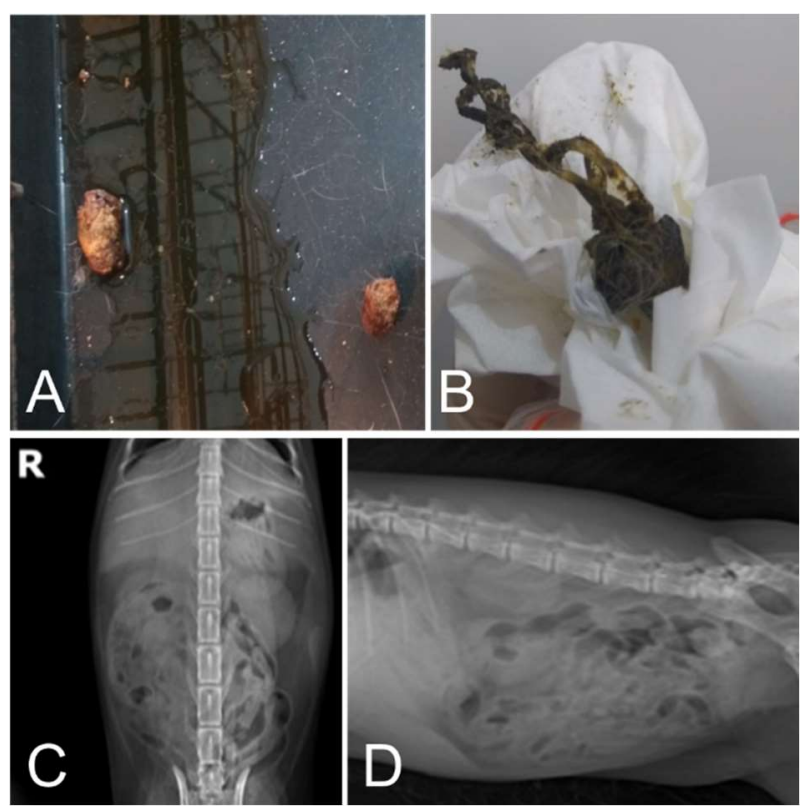

Gambar 1 Kondisi feses (A), temuan benda asing saat nekropsi (B), dan citra radiografi pada sudut pandang dorso-ventral (C) dan latero-lateral (D) kucing Caca.

Diterima: 10-01-2021 | Direvisi: 15-02-2021 | Disetujui: 17-02-202 (C) 2021 CC-BY-SA. Ini adalah artikel Open Access yang didistribusikan berdasarkan ketentuan dari Creative Commons Attribution ShareAlike 4.0 International License (https://creativecommons.org/licenses/by-sa/4.0/). 
Pemeriksaan histopatologi: Hari ke 8 kondisi kucing Caca semakin memburuk setelah tidak dapat buang air besar selama 7 hari, mengalami kematian, dilakukan nekropsi dan ditemukan benda asing dalam ileum (Gambar 1B).

\section{- HASIL DAN PEMBAHASAN}

Pemeriksaan histopatologi organ ileum terlihat adanya kerusakan jaringan hingga lapisan submukosa (Gambar 2). Kerusakan lapisan yang terlihat berupa terjadinya ruptur lapisan mukosa hingga beberapa bagian kripta Lieberkuhn. Keberadaan benda asing (Gambar 1B) pada usus kucing Caca selain mengkibatkan ruptur hingga lapisan mukosa juga menyebabkan peradangan pada lapisan mukosa yang terlihat dari adanya infiltrasi sel radang. Jenis sel radang yang sering ditemukan adalah makrofag, netrofil, limfosit atau sel plasma. Menurut Gomes et al. (2020), ruptur adalah robek atau putusnya jaringan secara paksa. Ruptur dapat terjadi karena adanya trauma. Menurut Cheville (2006), eksudat purulen umumnya bercampur dengan fibrin dan mukus.

Tabel 2 Hasil pemeriksaan darah kucing Caca

\begin{tabular}{|lllll|}
\hline Pemeriksaan & Satuan & Hasil & Standar & Keterangan \\
\hline $\mathrm{WBC}$ & $10^{3} / \mathrm{Ul}$ & 12,3 & $5,5-19,5$ & Normal \\
$\mathrm{RBC}$ & $10^{6} / \mathrm{Ul}$ & 5,46 & $5,0-10,0$ & Normal \\
$\mathrm{Hb}$ & $\mathrm{g} / \mathrm{dL}$ & 4,2 & $8,0-15,0$ & Turun \\
$\mathrm{HCT}$ & $\%$ & 25,4 & $24,0-45,0$ & Normal \\
$\mathrm{MCV}$ & $\mathrm{fL}$ & 46,5 & $39,0-55,0$ & Normal \\
$\mathrm{MCH}$ & $\mathrm{pg}$ & 7,7 & $12,5-17,5$ & Turun \\
$\mathrm{MCHC}$ & $\mathrm{g} / \mathrm{Dl}$ & 16,5 & $30,0-36,0$ & Turun \\
$\mathrm{PLT}$ & $10^{3} / \mathrm{L}$ & 76 & $300-800$ & Turun \\
Limfosit & $\%$ & 7,4 & $20,0-55,0$ & Turun \\
Monosit & $\%$ & 3,1 & $1,0-4,0$ & Normal \\
Granulosit & $\%$ & 89,5 & $35,0-78,0$ & Normal \\
Limfosit & $10^{3} / \mathrm{L}$ & 0,9 & $1,5-7,0$ & Naik \\
Monosit & $10^{3} / \mathrm{L}$ & 0,4 & $0,0-0,85$ & Turun \\
Granulosit & $10^{3} / \mathrm{L}$ & 11,0 & $2,5-1,4$ & Normal \\
\hline
\end{tabular}

Keterangan: WBC (sel darah putih), RBC (sel darah merah), $\mathrm{Hb}$ (hemoglobin), HCT (hematokrit), MCV (mean corpuscular volume), $\mathrm{MCH}$ (mean corpuscular hemoglobin), MCHC (mean corpuscular hemoglobin concentration), PLT (platelet)

Piknosis merupakan salah satu fase dari nekrosis koagulatif. Nekrosis koagulatif respon awal yang seringkali muncul akibat hypoxia, ischemia atau kerusakan yang disebabkan toksin. Fase awal yang terjadi pada nekrosis koagulatif adalah piknosis yang ditandai dengan nukleus yang terkondensasi, kemudian fase karioreksis yang ditandai dengan nukleus yang terfragmen dan fase akhirnya adalah kariolisis yang ditandai dengan nukleus yang melebur atau lisis (Zachary \& McGavin 2013).

Nekrosis koagulatif terjadi akibat hilangnya secara mendadak fungsi sel akibat hambatan kerja pada sebagian besar enzim. Enzim sitoplasmik hidrolitik juga dihambat sehingga tidak terjadi penghancuran sel (proses autolisis minimal). Sehingga struktur jaringan yang mati masih dipertahankan, terutama pada tahap awal (Sarjadi 2003). Menurut Pringgoutomo et al. (2002), nekrosis koagulatif terjadi pada nekrosis iskemik akibat putusnya perbekalan darah. Daerah yang terkena menjadi padat, pucat dikelilingi oleh daerah yang hemoragik mikroskopik tampak inti-inti yang piknotik. Sesudah beberapa hari sisa-sisa inti menghilang, sitoplasma tampak berbutir, berwarna merah tua. Sampai beberapa minggu rangka sel masih dapat dilihat.

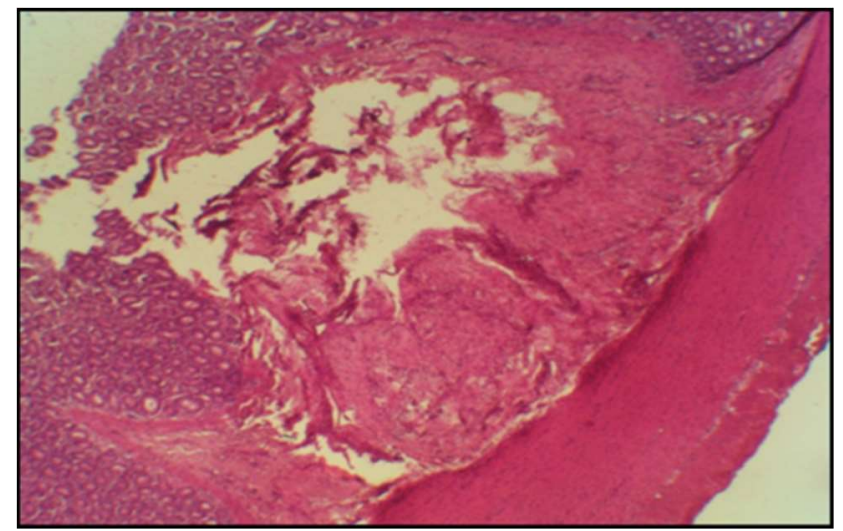

Gambar 2 Histopatologi ileum kucing Caca tampak adanya ruptur pada bagian submukosa sehingga tidak terlihat batas-batas yang jelas.

\section{- SIMPULAN}

Berdasarkan hasil pemeriksaan histopatologi kucing Caca mengalami obstruksi benda asing (corpora aliena) yang ditunjukkan dengan adanya ruptur bagian submukosa ileum.

\section{- INFORMASI PENULIS}

\section{Penulis Korespondensi}

*MAL: arfan_lesmana@ub.ac.id

Departemen Klinik, Fakultas Kedokteran Hewan, Universitas Brawijaya, Malang, Jawa Timur, INDONESIA.

\section{- PUSTAKA ACUAN}

Cheville NF. 2006. Introduction to Veterinary Pathology. Ed ke-3. USA: Blackwell Publishing.

Erwin E, Rusli R, Amiruddin A, Noviana D, Soesatyoratih RR, Fitri AD, Siallagan SF. 2018. Penanganan Obstruksi Duodenum pada Anjing: Laporan Kasus. Jurnal Veteriner 19(1):137-142.

Gomes FC, Anunciação JW, Guedes PE, Carlos RS. 2020. Intestinal Rupture Due to a Non-Perforating Foreign Body. Acta Scientiae Veterinariae 48(1):519.

Kyles AE, Schneider TA, Clare A. 1998. Foreign body intestinal perforation and intra-abdominal abscess formation as a complication of enteroplication in a dog. The Veterinary Record. 143(4):112-3.

Mahajan SK, Anand A, Sangwan V, Mohindroo J, Singh K. 2012. Surgical retrieval of a metallic foreign body from the spleen of a dog. The Canadian Veterinary Journal. 53(4):399.

Pringgoutomo S, Himawan S, Tjarta A. 2002. Buku Ajar Patologi I. Jakarta : Sagung Seto.

Sarjadi. 2003. Patologi Umum. Semarang: Badan Penerbit Universitas Diponegoro

Zachary JF, McGavin MD. 2013. Pathologic Basis of Veterinary Disease-E-Book. Elsevier Health Sciences; 2013 Dec 11. 